\title{
Resource-efficient intelligent transportation systems as a basis for sustainable development. Overview of initiatives and strategies
}

\section{Yuriy Vovk}

Ternopil Ivan Pul'uj National Technical University, 56 Ruska str., 46001 Ternopil, Ukraine

PhD, Associate Professor, Department of Transport Technology

\section{open 2 access (c) dol}

Article history:

Received: October, 2016

1st Revision: October, 2016

Accepted: November, 2016

doi: $10.14254 /$ jsdtl.2016.1-1.1

\begin{abstract}
Intelligent transportation systems mostly operate on information exchange principle between vehicles and roadside infrastructure. They are commonly regarded as a base technology for persistent diminution of road accidents and traffic efficiency increase. However, intelligent transportation systems can also be used at all levels of transportation systems as a basis for stable development of cities, enterprises, regions, states, continents. According to the research, the existing intelligent transportation systems not only provide the considerable reduction of greenhouse gases emissions, fuel saving, time of travel cutting, but they don't marginalize citizens' mobility as well. Thus, the further development and introduction of modern transportation innovative technologies will allow to guarantee the power- and resources efficiency and, therefore, the sustainable development of the whole society.
\end{abstract}

Keywords: intelligent transportation systems, communications technology, telecommunication standards, safety, resource-efficiency, energy efficiency, vehicles.

\section{Introduction}

Intelligent transportation system (ITS) is a transportation system which applies innovative developments in traffic flow modeling and regulating aimed at final consumers be well-informed and safe and to increase greatly the traffic participants level of interaction compared to conventional transportation systems (Directive EU, 2010).

Although ITS may refer to all modes of transport, EU Directive 2010/40/EU (7 July 2010) defined ITS as systems in which information and communication technologies are applied in the field of road transport, including infrastructure, vehicles and users, and in traffic management and mobility management, as well as for interfaces with other modes of transport (Directive 2010/40/EU).

Intelligent transportation systems (ITS) apply modern technologies to improve transport networks.

ITS is a collective term whilst using electronics, communications, information processing technology etc. The very name of "ITS" was originally used by Japanese professionals at the conference in Yokohama in 1995. 
ITS is an integration of information-communication technologies between main constituents of transportation processes: man-vehicle-infrastructure (Rudzinsky \& Melnichuk, 2012).

\section{Main material}

Rapid progress in the field of computation engineering and mobile communication has caused the boom in such systems development and reduce cost for smart/electronic devices use, making them affordable for millions of consumers.

Programs for the travel online planning, car navigators, digital maps-guidebooks, automatic road data - all these are the examples of intelligent transportation systems (ITS).

Actually, any transport-technology combination can be referred to as an "intelligent" one, and possibilities of ITS application are practically unlimited.

ITS can be divided into so called sub-categories (ITS Ukraine, 2016) (fig. 1):

- safe ITS;

- intelligent ITS;

- environmentally safe ITS.

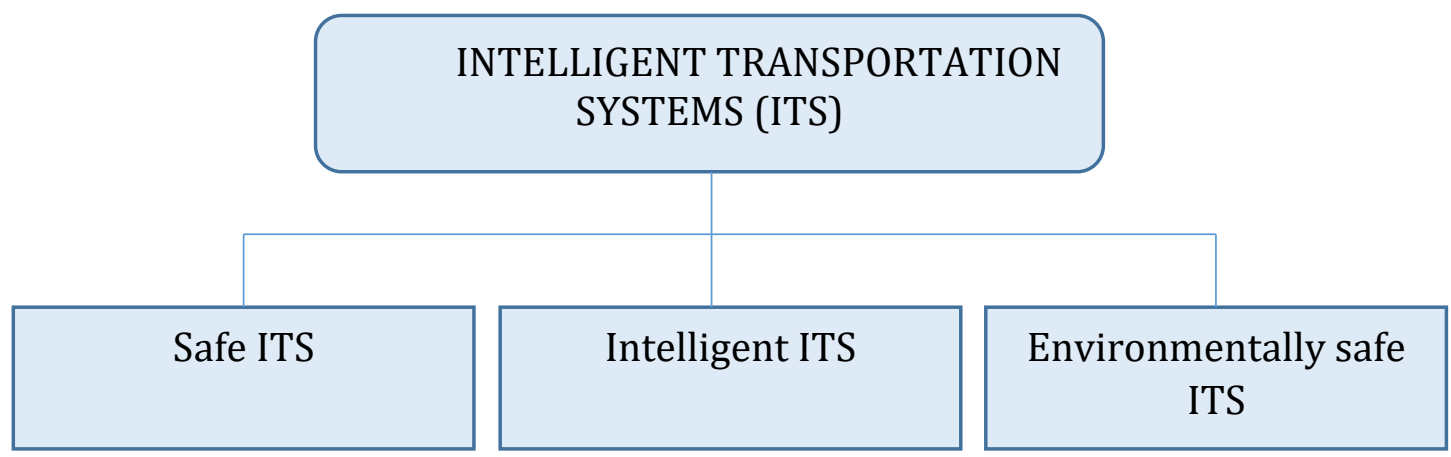

Fig. 1. Sub-categories of intelligent transportation systems

Safe ITS are focused on safety and reducing the number of accidents and injuries dealing with traffic.

Most early systems and projects can be referred to as safe ITS.

In Europe, the first research programs for cooperative ITS date back to the 1980s; the European project PROMETHEUS (1987-1994) marked the beginning of a cooperative driving system using inter-vehicle communication in the $57 \mathrm{GHz}$ frequency band (Festag, 2014). By 2000, a new wave of research and development activities in academia and industry was initiated worldwide, triggered by the availability of GPS, embedded systems, and WiFi. In Europe, more than 40 different projects on C-ITS have been initiated since 2000. Starting with initial feasibility studies, such as FleetNet and NoW, projects greatly contributed to the current technology state and standardization, for example, SAFESPOT, GeoNet, SEVECOM, CoVeL, and COMeSafety. Finally, field operation tests (DRIVE C2X, SIM-TD, SCORE@F, etc.) validated and assessed the potential positive impact of CITS on safety and traffic efficiency at various test sites across Europe. Further projects have been initiated to study cooperative automated driving, such as the AutoNet2030 project (Festag, 2014).

Vehicles are getting safer, cleaner, and more intelligent. Various sensors and assistant systems enable vehicles to monitor their environment. By means of information exchange among vehicles, as well as between vehicles and the roadside infrastructure, vehicles transform from autonomous systems into cooperative systems. Inter-vehicle communication is a cornerstone of Intelligent Transportation Systems (ITS), commonly referred to as cooperative ITS (C-ITS) or car-2-X communication (Festag, 2014).

The development of C-ITS is primarily driven by applications for active road safety and traffic efficiency, which help drivers to be aware of other vehicles, disseminate warnings about road hazards, and provide realtime information about traffic conditions for speed management and navigation. Typically, these C-ITS applications rely on always-on connectivity among the vehicles in the vicinity, including the roadside infrastructure, and frequent data exchange. Additionally, Internet access and location-based services, such as for point-of-interest notification, road access control, and parking management, improve the driving convenience. Among the various possible communication technologies for ITS, a dedicated variant of IEEE 802.11, an allocated frequency band at $5.9 \mathrm{GHz}$ for road safety and traffic efficiency applications, ad hoc networking, and C-ITS specific message sets have emerged as the current state of the art (Festag, 2014).

Nowadays ITSs is the largest and the most versatile group. It includes not only a great variety of information, road, navigating, car systems but insurance and control systems for a vehicle/ driver (telematics) and thousands other systems using data to make "intelligent" transport-related decisions. Most transport-related "applications" which are available on modern smartphones belong to this category. ITSs guarantee enormous 
economic benefits as both carriers and transport users will be able to make more reasonable decisions to reduce passengers and cargo transportation time and to cut transportation expenditures and delays.

Environmentally safe ITSs, sometimes referred to as "eco" or "green" ITSs, apply technologies to reduce the impact of passengers and cargo transportation on the environment. Along with intelligent TSs, environmentally safe ITSs contribute to cut emissions and fuel consumption and help to develop new, ecologically resistant transportation-related decisions. Environmentally safe ITSs have great chances to assist emissions reduction and to minimize transportation effect on the environment, especially at present, when individual mobility is constantly growing.

One of the perfect examples of environmentally safe intelligent transportation systems development in Ukraine is project called "Tesla Club Ukraine". The project assists the popularization of electric vehicles and also concerning their specific functions and correct use. At present the main objective of the club is to develop infrastructure to recharge electric motor cars. Together with its partners the club installed and opened 78 recharge stations absolutely free and easy in use. One more interesting example is a mobile application To-U aimed at comfortable use of free battery chargers Keba P20 around Ukraine, mapping the best route to the nearest recharge station, a charger reservation for the most suitable time. The mobile application allows to spend less time and efforts to recharge an electric motor car (Tesla Club Ukraine, 2016).

There are a lot of similar examples of ITSs implementations in Ukraine but they aren't of systemic nature as they are introduced locally and occasionally. (Rudzinsky \& Melnichuk, 2012).

Thus, it would make sense to study the evolution of intelligent transportation systems strategies. Here, the research of motor transport communication systems seems to be quite useful. (Papadimitratos et al., 2009), where a great deal of projects and initiatives have been summarized concerning intelligent transportation systems development at all levels since 2002.

The development of such Vehicular Communication Systems (VC Systems) and related technologies has been the subject of numerous projects around the globe, as well as for standardization working groups and industrial consortia. Authors (Papadimitratos et al., 2009) summarize the large majority of such recent efforts in Table 1, with projects having complementary but often similar objectives and approaches. The table summarizes the objectives of each project, consortium, or initiative, along with its duration and context.

As we can see from this incomplete list of motor transport communication systems, there are a great number of initiatives which are very close as for their objectives and tasks but they don't have a common basis like standards, conceptions, strategies.

We must admit, some attempts are made to come to the European or global unifications and standardization level. In particular, for common ITSs (Cooperative-ITS) in Europe based on COMeSafety initiative (COMeSafety, 2009) common reference architecture is applied, with direct involvement from the European Telecommunications Standards Institute (ETSI) TC ITS and the International Organization for Standards (ISO) TC204 WG16 (ITS Communications).

The COMeSafety2 project is an EC-funded Support Action (7th Framework Programme) providing information to the EC about relevant technical and organisational matters related to vehicle-to-vehicle and vehicle-to-infrastructure communications as the basis for co-operative intelligent road transport systems. The project builds on the results of the COMeSafety Support Action in FP6 (2006-2009).

The overall goal of COMeSafety is to support realisation and possible deployment of cooperative communication-based active safety systems: it is dedicated to foster wide agreement on technical issues, but also on deployment strategies.

The project will support and coordinate the development of the necessary standards towards the realisation of cooperative systems on European roads, under the ITS standardisation mandate at ETSI and CEN. It will support EU-US international cooperation, exploiting intercontinental synergies of field operational tests. The project will also push the finalisation and implementation of the European ITS Communications Architecture.

The eCoMove 3-year integrated project (April 2010 - January 2014), funded by the European Commission under the 7th Framework Programme of Research and Technological Development followed the previous one.

This project has created an integrated solution for road transport energy efficiency to help drivers, freight and road operators:

- save unnecessary kilometres driven (optimised routing);

- save fuel (eco-driving support);

- manage traffic more efficiently (optimised network management). 


\begin{tabular}{|c|c|c|c|}
\hline \multirow{2}{*}{ Project name } & \multicolumn{3}{|r|}{ Project information } \\
\hline & Period & External funding & Brief description of objectives \\
\hline CyberMove & $\begin{array}{l}2001- \\
2004\end{array}$ & European Union & $\begin{array}{l}\text { Investigation toward new transportation systems based on CyberCars } \\
\text { (automated vehicles) as a complement to public mass transportation; } \\
\text { http://www.cybermove.org }\end{array}$ \\
\hline $\begin{array}{l}\text { IntelliDrive } \\
\text { Previously known } \\
\text { as the VII } \\
\text { consortium (VIIC) }\end{array}$ & $\begin{array}{l}\text { Ongoing } \\
2005- \\
2008\end{array}$ & $\begin{array}{l}\text { Department of } \\
\text { Transportation } \\
\text { USA }\end{array}$ & $\begin{array}{l}\text { Initiative of the ITS Joint Programs Office (JPO) at the DoT's Research and } \\
\text { Innovative Technology Administration (RITA) VC technologies and } \\
\text { applications, V2V, V2I, mobility, and policy research; } \\
\text { http://www.intellidriveusa.org/ }\end{array}$ \\
\hline CAMP/VSC-2 & $\begin{array}{l}2005- \\
2009\end{array}$ & $\begin{array}{l}\text { Department of } \\
\text { Transportation } \\
\text { USA }\end{array}$ & $\begin{array}{l}\text { Cooperative Intersection Collision Avoidance System - Violations (CICAS- } \\
\text { V); Emergency Electronic Brake Lights (EEBL); Vehicle Safety } \\
\text { Communications - Applications (VSC-A) }\end{array}$ \\
\hline AKTIV & $\begin{array}{l}2006- \\
2010\end{array}$ & $\begin{array}{l}\text { Ministry of } \\
\text { Economics and } \\
\text { Technology } \\
\text { Germany }\end{array}$ & $\begin{array}{l}\text { Design, development, and evaluation of driver assistance systems, } \\
\text { knowledge and information technologies, efficient traffic management, } \\
\text { and V2V and V2I communication; http://www.aktiv- } \\
\text { online.org/index.html }\end{array}$ \\
\hline $\begin{array}{l}\text { Car to Car } \\
\text { Communication } \\
\text { Consortium } \\
\text { (C2C-CC) }\end{array}$ & Ongoing & N/A & $\begin{array}{l}\text { Development of a European industry standard for VC communication } \\
\text { systems, active safety applications prototyping and demonstrations, } \\
\text { harmonization of VC standards worldwide, realistic deployment } \\
\text { strategies and business models; http://www.car-2-car.org/ }\end{array}$ \\
\hline CityMobil & $\begin{array}{l}2006- \\
2010 \\
\end{array}$ & European Union & $\begin{array}{l}\text { Integration of automated transport systems in the urban environment, } \\
\text { based on real-life implementations; http://www.citymobil-project.eu/ }\end{array}$ \\
\hline COOPERS & $\begin{array}{l}2006- \\
2010\end{array}$ & European Union & $\begin{array}{l}\text { Telematic applications for the road infrastructure, cooperative traffic } \\
\text { management involving vehicles and roadside infrastructure; } \\
\text { http://www.coopers-ip.eu/ }\end{array}$ \\
\hline CyberCars2 & $\begin{array}{l}2006- \\
2008 \\
\end{array}$ & European Union & $\begin{array}{l}\text { Cooperation between vehicles running at close range (platooning) and at } \\
\text { intersections (merging, crossing); http://www.cybercars.org }\end{array}$ \\
\hline SAFESPOT & $\begin{array}{l}2006- \\
2010\end{array}$ & European Union & $\begin{array}{l}\text { Ad hoc networking, accurate relative localization, dynamic local traffic } \\
\text { maps; scenario-based evaluation of safety applications; sustainable } \\
\text { deployment strategy; http://www.safespot-eu.org/ }\end{array}$ \\
\hline SmartWay & $\begin{array}{l}2006- \\
2010\end{array}$ & $\begin{array}{l}\text { Ministry of Land, } \\
\text { Infrastructure, } \\
\text { Transport and } \\
\text { Tourism Japan }\end{array}$ & $\begin{array}{l}\text { Driving safety support systems based on vehicle-highway cooperation; } \\
\text { http://www.mlit.go.jp/road/ITS/ }\end{array}$ \\
\hline CVIS & $\begin{array}{l}2007- \\
2011\end{array}$ & European Union & $\begin{array}{l}\text { Multichannel terminal capable of continuous Internet connection, open } \\
\text { communication architecture, enhanced positioning, commercial } \\
\text { applications, toolkit (models, guidelines, and recommendations), and } \\
\text { deployment roadmaps; http://www.cvisproject.org/ }\end{array}$ \\
\hline EVITA & $\begin{array}{l}2008- \\
2011\end{array}$ & European Union & $\begin{array}{l}\text { Secure and trustworthy intravehicular communication; architecture for } \\
\text { automotive onboard networks to thwart tampering and protect sensitive } \\
\text { data inside a vehicle; http://evita-project.org/ }\end{array}$ \\
\hline GeoNet & $\begin{array}{l}2008- \\
2009\end{array}$ & European Union & $\begin{array}{l}\text { Specifying, developing and testing IPv6 geo-networking that can be used } \\
\text { within a cooperative architecture (e.g., CVIS); http://www.geonet- } \\
\text { project.eu/ }\end{array}$ \\
\hline HAVE-IT & $\begin{array}{l}2008- \\
2011\end{array}$ & European Union & $\begin{array}{l}\text { Automated merging, queue assistance, temporary auto-pilot, and active } \\
\text { green driving mechanisms, integrated in six demonstrator vehicles; } \\
\text { http://www.haveit-eu.org }\end{array}$ \\
\hline ETSI TC ITS & Ongoing & $\mathrm{N} / \mathrm{A}$ & $\begin{array}{l}\text { Standardization activities to support the development and } \\
\text { implementation of intelligent transportation systems; } \\
\text { http://portal.etsi.org/Portal_Common/home.asp }\end{array}$ \\
\hline IEEE P1609 & Ongoing & $\mathrm{N} / \mathrm{A}$ & $\begin{array}{l}\text { Standard for wireless access in vehicular environments (WAVE) - } \\
\text { Resource manager, physical and medium access control, security } \\
\text { services, networking services, multichannel operations for V2V and V2I } \\
\text { communication; } \\
\text { http://www.standards.its.dot.gov/fact_sheet.asp?f=80 }\end{array}$ \\
\hline $\begin{array}{l}\text { ISO TC } 204 \\
\text { WG16/CALM }\end{array}$ & Ongoing & $\mathrm{N} / \mathrm{A}$ & $\begin{array}{l}\text { Standardized set of air interface protocols and parameters for medium- } \\
\text { and long-range high-speed ITS communication, across } \\
\text { several media, networking, and upper layer protocols; } \\
\text { http://www.isotc204wg16.org/ }\end{array}$ \\
\hline PATH & Ongoing & $\begin{array}{l}\text { California } \\
\text { Department of } \\
\text { Transportation } \\
\text { (CalTrans) }\end{array}$ & $\begin{array}{l}\text { Multidisciplinary research program administered by the UC Berkeley } \\
\text { Institute of Transportation Studies and CalTrans; activities in four areas: } \\
\text { policy and behavioral, transportation safety, and traffic and transit } \\
\text { operations research; http://www.path.berkeley.edu/ }\end{array}$ \\
\hline
\end{tabular}


The project's core concept is that there is a theoretical minimum energy consumption achievable with the "perfect eco-driver" travelling through the "perfectly eco-managed" road network (eCoMove).

eCoMove is one of the first initiatives to apply to a new application field (energy efficiency) the results emerging from the previous generation of R\&D projects developing the core technologies and early applications based on vehicle-to-vehicle and vehicle-to-infrastructure communication.

In these projects, however, the emphasis was on traffic safety and efficiency rather than energy efficiency of an individual vehicle or of the whole road network (even though improving traffic flow by reducing stops also saves fuel consumption) (eCoMove).

\section{Conclusions and further research prospects}

Resource-efficient intelligent transportation systems, which will be based on tested, adopted for the society and certain consumers' needs, substantiated as for economic efficiency and sustainability strategies and initiatives, will be able to provide in future the transportation systems sustainable development in cities, enterprises, regions, states at micro-, meso- and macro levels. In this case it's necessary to make further research on resource-efficient innovative projects development and substantiation, hardware reliability assurance and information resources storage, standardization introducing and citizens' rights enforcement concerning the access limitation to personal information and personal affairs interference.

\section{References}

COMeSafety. (2009). Cooperative Mobility for Energy Efficiency. Retrieved from: http://www.ecomoveproject.eu/links/comesafety/ (November 10, 2016).

Directive 2010/40/EU of the European Parliament and of the council of 7 July 2010 on the framework for the deployment of Intelligent Transport Systems in the field of road transport and for interfaces with other modes of transport. Retrieved from: http://eurlex.europa.eu/LexUriServ/LexUriServ.do?uri=0J:L:2010:207:0001:0013:EN:PDF (in English).

eCoMove. Retrieved from: http://www.ecomove-project.eu (November 10, 2016).

Festag, A. (2014). Cooperative intelligent transport systems standards in Europe, IEEE Communications Magazine, 52 (12), 166-172. doi: 10.1109/MCOM.2014.6979970.

Papadimitratos, P., Fortelle La, A. D., Evenssen, K., Brignolo, R. and Cosenza, S. (2009). Vehicular communication systems: Enabling technologies, applications, and future outlook on intelligent transportation, IEEE Communications Magazine, 47 (11), 84-95. doi: 10.1109/MCOM.2009.5307471.

Rudzinsky, V.V., \& Melnichuk, S.V. (2012). Osoblyvosti pidhotovky fakhivtsiv za napriamkom intelektualni transportni systemy [Features training an expert in ITS]. Visnyk Zhytomyrskoho derzhavnoho tekhnolohichnoho universytetu. Seriia: Tekhnichni nauky = Bulletin Zhytomyr State Technological University. Series: Engineering, 3(62), 165-169. Retrieved from: http://vtn.ztu.edu.ua/article/view/49091/47653 (November 10, 2016) (in Ukrainian).

Shcho take Intelektualni transportni systemy? [What are Intelligent Transport Systems?]. (2016). ITS Ukraine, Retrieved from: http://its-ukraine.org/інтелектуальні-транспортні-системи/?lang=uk (November 10, 2016) (in Ukrainian).

Tesla Club Ukraine. (2016). Retrieved from: http://www.tesla-club.com.ua (November 10, 2016) (in Ukrainian).

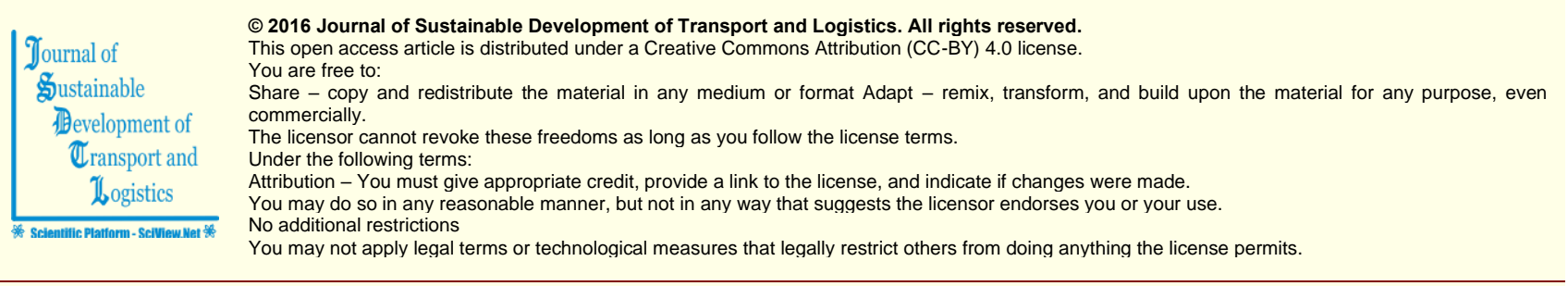

Journal of Sustainable Development of Transport and Logistics (ISSN: 2520-2979) is published by Scientific Publishing House "CSR",

Poland, EU and Scientific Publishing House "SciView", Ukraine

Publishing with JSDTL ensures:

- Immediate, universal access to your article on publication

- High visibility and discoverability via the JSDTL website

- Rapid publication

- Guaranteed legacy preservation of your article

- Discounts and waivers for authors in developing regions

Submit your manuscript to a JSDTL at http://jsdtl.sciview.net/ or submit.jsdtl@sciview.net 